\title{
Regression methods for evaluation of the underwater noise levels in the Slovenian Sea
}

\author{
Andreja Popit* \\ Institute for Water of the Republic of Slovenia \\ *Corresponding author: E-mail: andreja.popit@izvrs.si
}

\begin{abstract}
English
Anthropogenic underwater noise pollution of seas and oceans caused by shipping can have negative effects on marine animals. The aim of this study was to evaluate quantitatively how much the underwater noise levels in the Slovenian Sea were influenced by anthropogenic pressures and meteorological parameters in the period from 2015 until 2018. For this purpose, correlation method and least squares multiple linear regression analysis were used. The results of this study show that the correlation of underwater noise levels with the dredging activity is significant but low, while correlation with the ship densities is insignificant, which could be due to reduced sound wave propagation in the shallow sea levels. Correlation of the underwater noise levels with the wind speed was significant but low to medium, which could be explained by the breaking waves generated by the wind that produced sound.
\end{abstract}

Keywords: Underwater noise, correlation, multiple linear regression, anthropogenic pressures, meteorological parameters

\section{Introduction}

Anthropogenic noise pollution is present in a number of world's the seas and oceans, caused, in particular, by marine traffic. Continuous underwater noise from ships disturbs communication of marine mammals, such as dolphins and whales, which causes problems in their orientation, mating, and feeding that are critical to their survival $[1,2]$.

\begin{abstract}
Slovene
Antropogeno onesnaževanje morij in oceanov s podvodnim hrupom zaradi ladijskega prometa ima lahko negativen vpliv na morske živali. Cilj te študije je bil kvantitativno oceniti, koliko so bile vrednosti ravni podvodnega hrupa v slovenskem morju odvisne od antropogenih pritiskov in meteoroloških parametrov v obdobju od 2015 do 2018. V ta namen sta bili uporabljeni korelacijska metoda in multipla linearna regresijska analiza $\mathrm{z}$ metodo najmanjših kvadratov. Rezultati te študije so pokazali, da je bila korelacija ravni podvodnega hrupa $\mathrm{z}$ aktivnostjo poglabljanja morskega dna signifikantna, toda nizka, medtem ko je bila korelacija z gostoto ladij zanemarljiva, kar je lahko posledica zmanjšanega širjenja zvočnega valovanja v plitvem morju. Korelacija ravni podvodnega hrupa s hitrostjo vetra je bila signifikantna, vendar nizka do srednja, kar je mogoče razložiti z zvokom nastalim zaradi lomljenja valov, ki jih je generiral veter.
\end{abstract}

Ključne besede: Podvodni hrup, korelacija, multipla linearna regresija, antropogeni pritiski, meteorološki parametri

To study the correlations of underwater noise with ship traffic that is representative for shallow waters worldwide, examples were chosen in the Celtic and North Seas of the UK, the Scotian Shelf of Canada, the Guanabara Bay in Southeast Brazil and in the shallow waters of the Indian Ocean. An example of the underwater noise of biological origin was chosen in the lagoon of a coral atoll in the Indian Ocean. For correlations of underwater noise with the 
ship traffic representative of deep waters examples were chosen in the Northeast Pacific Ocean in the USA; the Ramsey Sound, Pembrokeshire, West Wales in the UK; and the Gulf of Mexico (Table 1).

An analysis of shallow-water ambient noise levels collected during 14 cruises was reported for the Scotian Shelf on the eastern Canadian coast over the period from 1972 to 1985 [3]. The frequency range covered was $30 \mathrm{~Hz}$ to 900 $\mathrm{Hz}$. It was found that the average ambient noise levels (Table 1) were characteristic of shallow water areas with high shipping densities.

The results of an analysis of temporal fluctuations in the noise power spectrum level of shallow water ambient noise in the bandwidth of $100 \mathrm{~Hz}$ to $4 \mathrm{kHz}$ were presented in India [4]. The results showed that variation in the average noise spectrum level was higher in the lower frequency level (100 Hz to $1 \mathrm{kHz}$ ) (Table 1 ) and assumed a constant level from there onwards. It was concluded that the temporal fluctuations of the noise levels were due mostly to ship traffic and changes in the weather conditions [4].

Frequency spectra of the underwater ambient noise were measured in the lagoon of a coral atoll, outside the reef and on shallow-water banks in the tropical zone of the Indian Ocean [5]. The measurements were performed in the frequency range of $0.003-9 \mathrm{kHz}$. In all the regions studied, continuous underwater noise (Table 1) of biological origin was observed, attributed to croaker fish [5].

Continuous measurements of underwater noise levels in the Northeast Pacific Ocean west of San Nicolas Island, California, USA over 138 days, spanning 2003-2004 were compared with measurements made during the 1960 s at the same site (Table 1) [6]. Ambient noise levels at $30-50 \mathrm{~Hz}$ were $10-12 \mathrm{~dB}$ higher in 2003-2004 than in 1964-1966 (Table 1), suggesting an average noise increase rate of $2.5-3 \mathrm{~dB}$ per decade. Low frequency $(10-50 \mathrm{~Hz})$ ocean ambient noise levels were closely related to the shipping vessel traffic. Increases in commercial shipping were believed to account for the observed low-frequency ambient noise increase. Above $50 \mathrm{~Hz}$ the noise level differences between recording periods gradually diminished to only $1-3 \mathrm{~dB}$ at $100-300 \mathrm{~Hz}$ [6].
Higher underwater noise levels were measured in the area of Ramsey Sound, Pembrokeshire, West Wales, UK, in the summer of 2009 during the season with increased boat traffic (Table 1) compared with the underwater noise levels measured in the spring of 2009 during the season with decreased boattraffic [7]. Below $2 \mathrm{kHz}$, the noise was thought to come from boat traffic. The peak in sound pressure level around $10 \mathrm{~Hz}$ in both seasons was thought to originate from a variety of shipping-related sources, including propeller-excited hull resonance, hull pressure, or propeller blades which could appear from 4 to $70 \mathrm{~Hz}$. These lower frequencies could originate from surface noise due to waves associated with shipping or from breaking on the rocks. The survey taken in the summer, during periods of increased tourist boat activity, showed a distinct peak around $100 \mathrm{~Hz}$ that was not apparent during the low season survey. The origin of this noise was likely to be diesel engines, propeller cavitation, engine harmonics and gearboxes [7].

The first study in Brazil to characterise noise levels in the coastal zone was carried out in Guanabara Bay (Southeast Brazil). It showed underwater noise pollution related to the ship traffic and small vessel traffic (Table 1) [8]. Locations with ship traffic had the highest noise levels, while locations with small vessel traffic had the lowest noise levels.

Elevated noise conditions were observed across the Gulf of Mexico, where anthropogenic marine activities were prominent [9]. The LF (low frequency) band was selected to include the environmental, meteorological, biological, and anthropogenic sounds that occur primarily between $10 \mathrm{~Hz}$ and $500 \mathrm{~Hz}$. At recording sites positioned nearest to high-density shipping lanes that lead to the Port of South Louisiana $(\mathrm{H}-3)$ and the Port of Houston $(\mathrm{H}-1)$ the highest $L_{01}$ values $(T=1 \mathrm{~h})$ were recorded (Table 1$)$ [9]. Nationally coordinated efforts to quantify underwater noise levels in the UK were presented, in support of UK policy objectives under the EU Marine Strategy Framework Directive (MSFD) [10]. Field measurements were made during 2013 and 2014 at twelve sites around the UK (Table 1). Noise exposure varied considerably, with little anthropogenic influence 


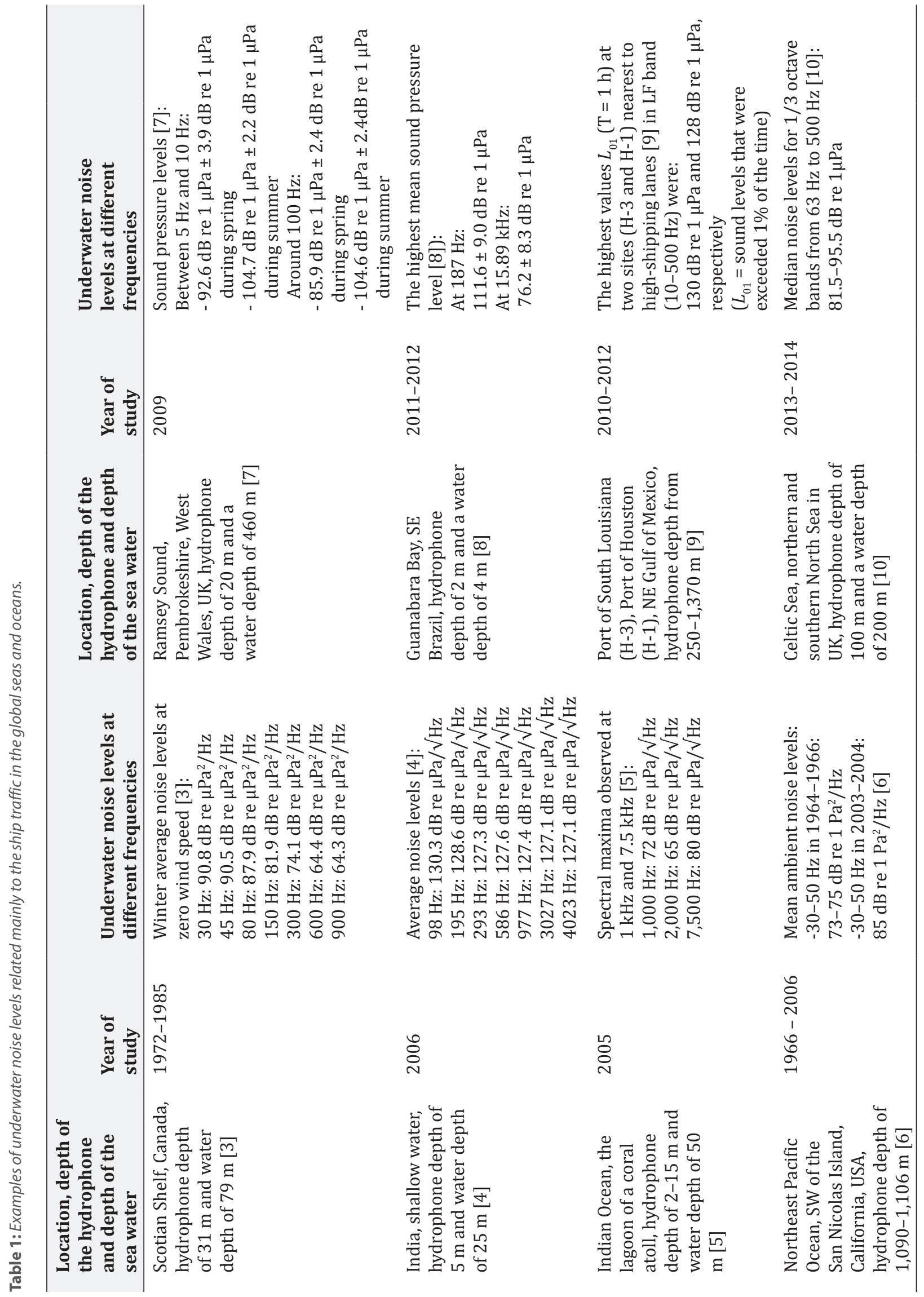


at the Celtic Sea site to several North Sea sites with persistent vessel noise [10].

The above studies showed that man-made noise pollution is present in a number of world seas and oceans caused, in particular, by the maritime traffic (Table 1 ).

In January 2019, a group of NGOs specialising in the protection of marine life warned that most EU member states were probably not going to honour their commitment to reduce marine noise pollution by 2020 [11]. In this regard, methodological guidance on the underwater noise mitigation measures were prepared by ACCOBAMS in 2019 [12]. These are very useful to be taken into consideration in order to successfully mitigate underwater noise sources in the worlds' seas and oceans.

The aim of this study was to prepare a methodology for quantitative determination of the relationship of the measured underwater noise levels in the Slovenian Sea with anthropogenic pressures and meteorological parameters.

The content of the study is important primarily from the point of view of properly recognising the correlation between the pressures and the status of the marine environment and of determining the optimal mitigating measures for achieving the objective of the Marine Directive (2008/56/EC) [13].

\section{Materials and methods}

Underwater noise is monitored near the lighthouse foundation $300 \mathrm{~m}$ off the coast at Debeli rtič, Slovenia (lat.: 453' 28.2" N, lon.: $13^{\circ} 41^{\prime}$ 59.1" E), beginning in February 2015. Hydrophone of type Bruel and Kjaer 8,105 was installed $1 \mathrm{~m}$ away from the lighthouse foundation at a depth of $4 \mathrm{~m}$ (sea depth is $5 \mathrm{~m}$ ) and connected to a sound analyser of type Bruel and Kjaer 2,250, with a sound level meter and an octave-based frequency analyser that operates in the frequency range of $6.3 \mathrm{~Hz}$ to $20 \mathrm{kHz}$ [14]. A sound analyser is closed inside the lighthouse. Measuring unit of the underwater noise levels is $\mathrm{dB}$ re $\mu \mathrm{Pa}$.

Dependent variables were continuous underwater noise levels (in $\mathrm{dB}$ ) in $1 / 3$ octave bands with center frequencies of $63 \mathrm{~Hz}$ and $125 \mathrm{~Hz}, L_{e q^{\prime} 63 \mathrm{~Hz}}$ and $L_{e q^{\prime} 125 \mathrm{~Hz}}(\mathrm{~dB})$. Independent variables were ship densities in the four different areas of $2 \mathrm{NM}$ and $5 \mathrm{NM}$ from the measuring station, in the Gulf of Trieste and in the Gulf of Venice $\left(\rho_{L, 2 \mathrm{NM}}, \rho_{L, 5 \mathrm{NM}}, \rho_{L, \text { Trieste }}, \rho_{L, \text { Venice }}\right)$, dredging activities, cleaning of the sea floor, wind speed at $v_{v}(\mathrm{~m} / \mathrm{s})$ and precipitation at $h_{p}(\mathrm{~mm})$. Wind speed data from the Piran buoy and precipitation data from the meteorological station in the Port of Koper were obtained from the Environmental Agency of the Republic of Slovenia. Ship densities were provided from Automatic Information System data [15].

Measuring periods were the following: from 13 February 2015 to 5 May 2015; from 26 September 2015 to 31 December 2015; from 18 August 2016 to 1 November 2016; from 6 July 2017 to 27 August 2017; and from 18 August 2018 to 31 December 2018, in which measured underwater noise levels were available.

For the analysis of the correlation between the dependent variables and the independent variables, the Pearson correlation coefficient $r$ was used [16], which is a measure of the linear correlation between the two variables that gives information about the degree, or magnitude, of the association or correlation, as well as of the direction (+/-) of the relationship between the variables. It is most suitable for use if the distribution of variables is normal (or at least symmetric and unimodal). With $r$ we can examine whether two variables tend to move together. If the large values of one variable are related to the large values of the other variable, the correlation is positive. If the small values of one variable are related to the large values of the other variable, the correlation is negative. If the values of the two variables are not related, the correlation is close to or equal to 0 .

The results of the analysis of the correlation between dependent and independent variables are presented in tables, the results being interpreted and the weights of the influence of the anthropogenic and meteorological noise sources on the measured underwater noise levels estimated.

With this correlation analysis, the interdependence of dependent and independent variables was investigated, while multiple linear regressionanalysis wasused tostudyhowstrongly the values of the dependent variables were affected by the values of independent variables. 
To predict the dependent variables from independent variables, a linear regression model was used, including the least squares method, in which the sum of the squares of deviations is minimal.

The multiple correlation coefficient $r$ between the dependent variables and the independent variables was analysed, and the results are presented in the next section.

The quality of the regression model was evaluated based on the coefficient of determination $R^{2}$, which tells how much of the variance of the dependent variables is explained by the variability of the independent variable - ie explained variance. In the case of the linear regression, it is equal to the square of the Pearson correlation coefficient, $R^{2}$. However, $1-R^{2}$ is an unexplained variance and its root is a standard prediction error.

The test of statistical significance of the correlation was performed based on $p$-values (significance level). In the regression equation, those variables that have a $p$-value of less than 0.05 are significant, which means that there is less than a $5 \%$ probability that the correlation is due to an error, which means that there is a $95 \%$ probability that the variables are related to each other.

If the $p$-value is less than or equal to 0.05 $(p \leq 0.05)$, then the results can be generalised with high certainty (95\%) from the sample to the population, ie that there are differences between the two variables or that the two variables are interrelated. If the $p$-value is greater than $0.05(p>0.05)$, then the results cannot be generalised from the sample to the population, and we must interpret the results only at the sample level.

From the regression analysis, we estimated the weights of the influence of the anthropogenic and meteorological noise sources on the levels of underwater noise measured.

\section{Results and discussion}

The average $L_{e q, 63 \mathrm{~Hz}}$ and $L_{e q, 125 \mathrm{~Hz}}$ levels measured in the Slovenian Sea in the period between 2015 and 2018 were 82.8-101.1 $\mathrm{dB}$ re $1 \mu \mathrm{Pa}$ and 83.9-98.1 $\mathrm{dB}$ re $1 \mu \mathrm{Pa}$, respectively. The average ship densities were $2-252$. The average wind speed was $1.8-4.6 \mathrm{~m} / \mathrm{s}$ and the average precipitation was $0.02-0.07 \mathrm{~mm}$ [14].

\section{Results of the correlation analysis}

Interdependence between the dependent $\left(L_{e q, 63 \mathrm{~Hz}}\right.$ and $\left.L_{e q, 125 \mathrm{~Hz}}\right)$ and independent $\left(\rho_{L, 2 N M^{\prime}}\right.$ $\rho_{L, 5 N M^{\prime}} \rho_{L, \text { Trieste }} \rho_{L, \text { Venice, }}$ dreadg. act., clean. act., $v_{v}$ and $h_{p}$ ) variables using the Pearson correlation coefficients is presented in Table 2 (for $L_{e q, 63 \mathrm{~Hz}}$ ) and Table 3 (for $L_{e q, 125 \mathrm{~Hz}}$ ).

The highest correlation between the underwater noise and the anthropogenic noise sources was obtained between the $L_{e q, 63 \mathrm{~Hz}}$ and the dredging activities $(r=0.31)$ (Table 2). The highest correlation between the underwater noise $\left(L_{e q, 63 \mathrm{~Hz}}\right.$ and $\left.L_{e q, 125 \mathrm{~Hz}}\right)$ and the ship density $\left(\rho_{L, 2 \mathrm{NM}^{\prime}} \rho_{L, 5 \mathrm{NM}^{\prime}} \rho_{L, \text { Trieste' }} \rho_{L, \text { Venice }}\right)$ was 0.18 . Correlation between the underwater noise

Table 2. The Pearson correlation coefficients between the dependent variable $\left(L_{\text {eq, } 63 \mathrm{H}}\right)$ and the independent variables $\left(\rho_{L, 2 N M^{\prime}} \rho_{L, 5 N M^{\prime}} \rho_{L, \text { Trieste }} \rho_{L, \text { venice., }}\right.$ dreadg. act., clean. act., $v_{v}$ and $\left.h_{p}\right)$ in all measuring periods.

\begin{tabular}{cccccc}
\hline $\begin{array}{c}\text { Pearson's } \\
\text { correlation } \\
\text { coefficient }\end{array}$ & $\begin{array}{c}\text { From } \\
\mathbf{1 3 . 0 2 . 2 0 1 5} \text { to } \\
\mathbf{0 5 . 0 5 . 2 0 1 5}\end{array}$ & $\begin{array}{c}\mathbf{2 6 . 0 9 . 2 0 1 5} \text { to } \\
\mathbf{3 1 . 1 2 . 2 0 1 5}\end{array}$ & $\begin{array}{c}\mathbf{1 8 . 0 8 . 2 0 1 6} \text { to } \\
\mathbf{0 1 . 1 1 . 2 0 1 6}\end{array}$ & $\begin{array}{c}\text { From } \\
\mathbf{0 6 . 0 7 . 2 0 1 7} \text { to }\end{array}$ & $\begin{array}{c}\text { From } \\
\mathbf{1 8 . 0 8 . 2 0 1 8} \text { to }\end{array}$ \\
\hline$r\left(v_{v}\right)$ & 0.58 & 0.51 & 0.54 & 0.39 & $\mathbf{3 1 . 1 2 . 2 0 1 8}$ \\
$r\left(h_{p}\right)$ & -0.02 & 0.06 & 0.08 & 0.08 & 0.35 \\
$r\left(\rho_{L, 2 \mathrm{NM}}\right)$ & 0.13 & -0.06 & 0.05 & -0.04 & 0.07 \\
$r\left(\rho_{L, 5 \mathrm{NM}}\right)$ & 0.06 & -0.06 & 0.02 & 0.09 & 0.08 \\
$r\left(\rho_{L, \text { Trieste }}\right)$ & -0.02 & -0.03 & 0.08 & 0.12 & 0.12 \\
$r\left(\rho_{L, \text { Venice }}\right)$ & -0.10 & -0.05 & -0.05 & 0.01 & -0.11 \\
$r$ (dredg. act.) & n.a. & 0.31 & n.a. & n.a. & n.a. \\
$r$ (clean. act.) & n.a. & n.a. & -0.10 & n.a. & n.a. \\
\hline
\end{tabular}


Table 3: The Pearson correlation coefficients between the dependent variable $\left(L_{\text {eq, } 125 \mathrm{H}}\right)$ and the independent variables $\left(\rho_{L, 2 N M^{\prime}} \rho_{L, 5 N M^{\prime}} \rho_{L, \text { Trieste }} \rho_{L, \text { venice, }}\right.$ dreadg. act., clean. act., $v_{v}$ and $\left.h_{p}\right)$ in all measuring periods.

\begin{tabular}{cccccc}
\hline $\begin{array}{c}\text { Pearsons } \\
\text { correlation } \\
\text { coefficients }\end{array}$ & $\begin{array}{c}\text { From } \\
\mathbf{1 3 . 0 2 . 2 0 1 5} \text { to } \\
\mathbf{0 5 . 0 5 . 2 0 1 5}\end{array}$ & $\begin{array}{c}\mathbf{2 6 . 0 9 . 2 0 1 5} \text { to } \\
\mathbf{3 1 . 1 2 . 2 0 1 5}\end{array}$ & $\begin{array}{c}\text { 18.08.2016 to } \\
\mathbf{0 1 . 1 1 . 2 0 1 6}\end{array}$ & $\begin{array}{c}\text { From } \\
\mathbf{0 6 . 0 7 . 2 0 1 7} \text { to } \\
\mathbf{0 7 . 0 8 . 2 0 1 7}\end{array}$ & $\begin{array}{c}\text { From } \\
\mathbf{3 1 . 1 2 . 2 0 1 8} \text { to }\end{array}$ \\
\hline$r\left(v_{v}\right)$ & 0.39 & 0.18 & 0.55 & 0.24 & 0.15 \\
$r\left(h_{p}\right)$ & -0.02 & 0.01 & 0.09 & 0.04 & 0.02 \\
$r\left(\rho_{L, 2 \mathrm{NM}}\right)$ & 0.11 & 0.06 & 0.07 & 0.02 & 0.12 \\
$r\left(\rho_{L, 5 \mathrm{NM}}\right)$ & 0.05 & 0.05 & -0.04 & 0.17 & 0.02 \\
$r\left(\rho_{L, \text { Trieste }}\right)$ & -0.02 & 0.02 & 0.01 & 0.18 & 0.04 \\
$r\left(\rho_{L, \text { Venice }}\right)$ & -0.08 & -0.01 & -0.09 & -0.01 & -0.10 \\
$r($ dredg. act. $)$ & n.a. & 0.10 & n.a. & n.a. & n.a. \\
$r$ (clean. act.) & n.a. & n.a. & -0.10 & n.a. & n.a. \\
\hline
\end{tabular}

$\left(L_{e q, 63 \mathrm{~Hz}}\right.$ and $\left.L_{e q, 125 \mathrm{~Hz}}\right)$ and the cleaning of the sea floor was -0.10 .

Correlation analyses showed that the relationship between the $L_{e q, 63 \mathrm{~Hz}}$ and the $v_{v}$ was between 0.35 and 0.58 , while that between $L_{e q, 125 \mathrm{~Hz}}$ and the $v_{v}$, was between 0.15 and 0.55 . The relation between the underwater noise $\left(L_{e q, 63 \mathrm{~Hz}}\right.$ and $\left.L_{e q, 125 \mathrm{~Hz}}\right)$ and the meteorological parameter - precipitation, $h_{p}$ - was between -0.02 and 0.09 (Tables 2 and 3). These results of the correlation analyses are interpreted in the subsection discussion.

\section{Results of the multiple linear regression analysis}

Furthermore, the least squares multiple linear regression analysis in Table 4 shows how much the values of the dependent variables were affected by the values of the independent variables. The multiple correlation coefficients between the dependent variable $L_{e q, 63 \mathrm{~Hz}}$ and the independent variables in all measuring periods were moderate $(r=0.40-0.59)$, while those between the dependent variable $L_{e q, 125 \mathrm{~Hz}}$ and the independent variables were low to moderate $(r=0.21-0.59)$ (Table 4).

In the regression analysis, 16\%-35\% of the variance of the dependent variable $L_{e q, 63 \mathrm{~Hz}}$ and $5 \%-34 \%$ of the variance of the dependent variable $L_{e q, 125 \mathrm{~Hz}}$ can be explained by the variability of the independent variables $\left(\rho_{L, 2 N M^{\prime}} \rho_{L, 5 N M^{\prime}} \rho_{L, \text { Trieste }}\right.$ $\rho_{L, \text { Venice }}$ dreadg. act., clean. act., $v v$ and $h p$ ), with which the predictive power of the multiple regression model is shown (Table 5).

The statistical significance test of the correlation based on the $p$-value indicated that there was only one independent variable, wind speed vv, that had a significant correlation with both dependent variables $\left(L_{e q, 63 \mathrm{~Hz}}\right.$ and $\left.L_{e q, 125 \mathrm{~Hz}}\right)$ in all the measuring periods (Tables 6 and 7). Dredging and cleaning activities also had a significant correlation with $L_{e q, 63 \mathrm{~Hz}}$ and $L_{\text {eq,125Hz }}$. Precipitation, hp, was mostly insignificant. Ship densities $\left(\rho_{L, 2 N M^{\prime}} \rho_{L, 5 N M^{\prime}} \rho_{L^{\prime}}\right.$ Trieste, $\rho_{L}$ Venice) were in some cases significant and in some insignificant.

Subsequently, the multiple regression analysis was repeated without the insignificant independent variables in each measuring period. Regression equations in which the dependent variables $\left(L_{e q, 63 \mathrm{~Hz}}\right.$ and $\left.L_{e q, 125 \mathrm{~Hz}}\right)$ were predicted by the significant independent variables are presented in Tables 8 and 9.

\section{Discussion of the results}

The average continuous underwater noise levels $\left(L_{e q, 63 \mathrm{~Hz}}\right.$ and $\left.L_{e q, 125 \mathrm{~Hz}}\right)$ measured in the Slovenian Sea [13] were similar to those reported in the literature, which were related to the shipping noise (Table 1).

Multiple correlation coefficients between the dependent variables $\left(L_{e q, 63 \mathrm{~Hz}}\right.$ and $\left.L_{e q, 125 \mathrm{~Hz}}\right)$ and independent variables (anthropogenic 
Table 4: Multiple correlation coefficients $(r)$ between dependent variables $\left(L_{e q, 63 \mathrm{~Hz}}\right.$ and $L_{\text {eq, }, 125 \mathrm{~Hz}}$ ) and independent variables $\left(\rho_{L, 2 N M^{\prime}} \rho_{L, 5 N M^{\prime}} \rho_{L, \text { Trieste }} \rho_{L, \text { venice, }}\right.$ dreadg. act., clean. act., $v_{v}$ and $\left.h_{p}\right)$ in all measuring periods.

\begin{tabular}{cccccc}
\hline $\begin{array}{c}\text { Multiple } \\
\text { correlation } \\
\text { coefficients }\end{array}$ & $\begin{array}{c}\text { From } \\
\mathbf{1 3 . 0 2 . 2 0 1 5} \text { to }\end{array}$ & $\begin{array}{c}\text { From } \\
\mathbf{0 5 . 0 5 . 2 0 1 5}\end{array}$ & $\begin{array}{c}\mathbf{3 1 . 1 2 . 2 0 1 5} \\
\text { From }\end{array}$ & $\begin{array}{c}\text { From } \\
\mathbf{0 1 . 1 1 . 2 0 1 6}\end{array}$ & $\begin{array}{c}\text { From } \\
\mathbf{0 7 . 0 8 7 . 2 0 1 5} \text { to }\end{array}$ \\
\hline$r\left(L_{e q, 63 \mathrm{~Hz}}\right)$ & 0.59 & 0.55 & 0.57 & 0.40 & $\mathbf{1 8 . 0 8 . 2 0 1 8}$ to \\
$r\left(L_{e q, 125 \mathrm{~Hz}}\right)$ & 0.41 & 0.21 & 0.59 & 0.29 & 0.40 \\
\hline
\end{tabular}

Table 5: Coefficients of determination $\left(R^{2}\right)$ between the dependent variables $\left(L_{\text {eq, } 63 \mathrm{~Hz}}\right.$ and $\left.L_{\text {eq, } 125 \mathrm{H}}\right)$ and the independent variables $\left(\rho_{L, 2 N M^{\prime}} \rho_{L, 5 N M^{\prime}} \rho_{L, \text { Trieste }} \rho_{L, \text { venice, }}\right.$ dreadg. act., clean. act., $v_{v}$ and $\left.h_{p}\right)$ in all measuring periods.

\begin{tabular}{cccccc}
\hline $\begin{array}{c}\text { Coefficients of } \\
\text { determination }\end{array}$ & $\begin{array}{c}\text { From } \\
\mathbf{1 3 . 0 2 . 2 0 1 5} \text { to } \\
\mathbf{0 5 . 0 5 . 2 0 1 5}\end{array}$ & $\begin{array}{c}\mathbf{2 6 . 0 9 . 2 0 1 5} \text { to } \\
\mathbf{3 1 . 1 2 . 2 0 1 5}\end{array}$ & $\begin{array}{c}\text { From } \\
\mathbf{0 1 . 0 8 . 2 0 1 6} \text { to }\end{array}$ & $\begin{array}{c}\text { From } \\
\mathbf{0 6 . 0 7 . 2 0 1 7} \text { to }\end{array}$ & $\begin{array}{c}\text { From } \\
\mathbf{1 8 . 0 8 . 2 0 1 8} \text { to }\end{array}$ \\
\hline$R^{2}\left(L_{\text {eq, }, 3 \mathrm{~Hz}}\right)$ & 0.35 & 0.30 & 0.33 & 0.16 & 0.16 \\
$R^{2}\left(L_{\text {eq, }, 125 \mathrm{~Hz}}\right)$ & 0.17 & 0.05 & 0.34 & 0.09 & 0.05 \\
\hline
\end{tabular}

Table 6: Significant independent variables with p-values lower than 0.05, meaning that there was a more than $95 \%$ probability that these variables were related to the dependent variable $L_{\text {eq.63H. }}$. The grey fields indicate insignificant independent variables, with $p$-values greater than 0.05 . The abbreviation n.a. means not applicable.

\begin{tabular}{|c|c|c|c|c|c|}
\hline$p$-values & $\begin{array}{c}\text { From } \\
13.02 .2015 \text { to } \\
05.05 .2015\end{array}$ & $\begin{array}{c}\text { From } \\
26.09 .2015 \text { to } \\
31.12 .2015\end{array}$ & $\begin{array}{c}\text { From } \\
\text { 18.08.2016 to } \\
01.11 .2016\end{array}$ & $\begin{array}{c}\text { From } \\
06.07 .2017 \text { to } \\
07.08 .2017\end{array}$ & $\begin{array}{c}\text { From } \\
\text { 18.08.2018 to } \\
31.12 .2018\end{array}$ \\
\hline$p\left(v_{v}\right)$ & 0.000 & 0.000 & 0.000 & 0.000 & 0.000 \\
\hline$p\left(h_{p}\right)$ & 0.001 & 0.061 & 0.240 & 0.923 & 0.010 \\
\hline$p\left(\rho_{L, 2 \mathrm{NM}}\right)$ & 0.005 & 0.691 & 0.048 & 0.003 & 0.036 \\
\hline$p\left(\rho_{L, 5 \mathrm{NM}}\right)$ & 0.007 & 0.015 & 0.000 & 0.556 & 0.000 \\
\hline$p\left(\rho_{L, \text { Trieste }}\right)$ & 0.327 & 0.794 & 0.000 & 0.119 & 0.000 \\
\hline$p\left(\rho_{L, \text { Venice }}\right)$ & 0.037 & 0.087 & 0.023 & 0.342 & 0.000 \\
\hline$p$ (dredg. act.) & n.a. & 0.000 & n.a. & n.a. & n.a. \\
\hline$p$ (clean. act.) & n.a. & n.a. & 0.002 & n.a. & n.a. \\
\hline
\end{tabular}

Table 7: Significant independent variables with p-values less than 0.05, meaning that there was a more than $95 \%$ probability that these variables were related to the dependent variable $L_{\text {ea, } 125 \mathrm{~Hz}}$. The grey fields indicate insignificant independent variables with $p$-values greater than 0.05 . The abbreviation n.a. means not applicable.

\begin{tabular}{|c|c|c|c|c|c|}
\hline$p$-values & $\begin{array}{c}\text { From } \\
13.02 .2015 \text { to } \\
05.05 .2015\end{array}$ & $\begin{array}{c}\text { From } \\
26.09 .2015 \text { to } \\
31.12 .2015\end{array}$ & $\begin{array}{c}\text { From } \\
\text { 18.08.2016 to } \\
01.11 .2016\end{array}$ & $\begin{array}{c}\text { From } \\
06.07 .2017 \text { to } \\
07.08 .2017\end{array}$ & $\begin{array}{c}\text { From } \\
18.08 .2018 \text { to } \\
31.12 .2018\end{array}$ \\
\hline$p\left(v_{v}\right)$ & 0.000 & 0.000 & 0.000 & 0.000 & 0.000 \\
\hline$p\left(h_{p}\right)$ & 0.019 & 0.509 & 0.111 & 0.867 & 0.599 \\
\hline$p\left(\rho_{L, 2 \mathrm{NM}}\right)$ & 0.097 & 0.022 & 0.000 & 0.033 & 0.000 \\
\hline$p\left(\rho_{L, 5 \mathrm{NM}}\right)$ & 0.000 & 0.000 & 0.000 & 0.215 & 0.002 \\
\hline$p\left(\rho_{L, \text { Tireste }}\right)$ & 0.001 & 0.000 & 0.000 & 0.033 & 0.000 \\
\hline$p\left(\rho_{L, \text { Venice }}\right)$ & 0.256 & 0.110 & 0.036 & 0.000 & 0.000 \\
\hline$p$ (dredg. act.) & n.a. & 0.000 & n.a. & n.a. & n.a. \\
\hline$p$ (clean. act.) & n.a. & n.a. & 0.021 & n.a. & n.a. \\
\hline
\end{tabular}


Table 8: Regression equations in which the dependent variable $L_{\text {eq, } 63 \mathrm{~Hz}}$ was predicted by the significant independent variables $\left(\rho_{L, 2 N M^{\prime}} \rho_{L, 5 N M^{\prime}} \rho_{L, \text { Trieste }} \rho_{L, \text { Venice, }}\right.$ dreadg. act., clean. act., $v_{v}$ and $\left.h_{p}\right)$.

\begin{tabular}{|c|c|}
\hline Measuring periods & Regression equations \\
\hline 13.02.2015-05.05.2015 & $\begin{array}{l}L_{e q, 63 \mathrm{~Hz}}=1.378 * v_{v}-3.898 * h_{p}+0.357 * \rho_{L, 2 \mathrm{NM}}+0.103 * \rho_{L, 5 \mathrm{NM}}-0.014^{*} \rho_{L, \text { Venice }}+ \\
63.450\end{array}$ \\
\hline 26.09.2015-31.12.2015 & $L_{e q, 63 \mathrm{~Hz}}=1.117 * v_{v}-0.093 * \rho_{L, 5 \mathrm{NM}}+4.304 *$ dred.act. +67.800 \\
\hline 18.08.2016-01.11.2016 & $\begin{array}{l}L_{e q, 63 \mathrm{~Hz}}=2.227^{*} v_{v}+0.165^{*} \rho_{L, 2 \mathrm{NM}}-0.627^{*} \rho_{L, 5 \mathrm{NM}}+0.528^{*} \rho_{L, \text { Trieste }}-0.012^{*} \rho_{L, \text { Venice }} \\
-3.1^{*} \text { clean.a. }+81.77\end{array}$ \\
\hline 06.07.2017-07.08.2017 & $L_{e q, 63 \mathrm{~Hz}}=2.762 * v_{v}-0.196 * \rho_{L, 2 \mathrm{NM}}+70.065$ \\
\hline 18.08.2018-31.12.2018 & $\begin{array}{l}L_{e q, 63 \mathrm{~Hz}}=1.555^{*} v_{v}+1.116 * h_{p}+0.112^{*} \rho_{L, 2 \mathrm{NM}}-0.216^{*} \rho_{L, 5 \mathrm{NM}}+0.268^{*} \rho_{L, \text { Trieste }}- \\
0.022^{*} \rho_{L, \text { Venice }}+73.576\end{array}$ \\
\hline
\end{tabular}

Table 9: Regression equations in which the dependent variable $L_{\text {eq, } 125 \mathrm{~Hz}}$ was predicted by the significant independent variables $\left(\rho_{L, 2 N M^{\prime}} \rho_{L, 5 N M^{\prime}} \rho_{L, \text { Trieste }} \rho_{L, \text { Venice, }}\right.$ dreadg. act., clean. act., $v_{v}$ and $\left.h_{p}\right)$.

\begin{tabular}{|c|c|}
\hline Measuring periods & Regression equations \\
\hline 13.02.2015-05.05.2015 & $L_{e q, 125 \mathrm{~Hz}}=0.752 * v_{v}-2.659 * h_{p}+0.263^{*} \rho_{L, 5 \mathrm{NM}}-0.153^{*} \rho_{L, \text { Trieste }}+77.786$ \\
\hline 26.09.2015-31.12.2015 & $\begin{array}{l}L_{e q, 125 \mathrm{~Hz}}=0.248^{*} v_{v}+0.192^{*} \rho_{L, 2 \mathrm{NM}}+0.167^{*} \rho_{L, 5 \mathrm{NM}}-0.117^{*} \rho_{L, \text { Trieste }}+1.181^{*} \text { dred. } \\
+77.375\end{array}$ \\
\hline 18.08.2016-01.11.2016 & $\begin{array}{l}L_{e q, 125 \mathrm{~Hz}}=1.869^{*} v_{v}+0.265^{*} \rho_{L, 2 \mathrm{NM}}-0.551^{*} \rho_{L, 5 \mathrm{NM}}+0.368^{*} \rho_{L, \text { Trieste }}- \\
0.009^{*} \rho_{L, \text { Venice }}-1.87^{*} \text { clean.a. }+84.6\end{array}$ \\
\hline 06.07.2017-07.08.2017 & $L_{e q, 125 \mathrm{~Hz}}=1.063^{*} v_{v}-0.122^{*} \rho_{L, 2 \mathrm{NM}}+0.151^{*} \rho_{L, \text { Triestre }}-0.017^{*} \rho_{L, \text { Venice }}+71.912$ \\
\hline 18.08.2018-31.12.2018 & $\begin{array}{l}L_{e q, 125 \mathrm{~Hz}}=0.562^{*} v_{v}+0.364^{*} \rho_{L, 2 \mathrm{NM}}-0.126^{*} \rho_{L, 5 \mathrm{NM}}+0.121^{*} \rho_{L, \text { Trieste }}-0.017 * \rho_{L, \text { Venice }} \\
+91.705\end{array}$ \\
\hline
\end{tabular}

pressures and meteorological parameters) were low to moderate $(r=0.21-0.59)$ (Table 4). In the regression analysis up to $35 \%$ of the variance of the dependent variable can be explained by the independent variables (Table 5).

The correlation coefficient between the measured underwater noise levels $\left(L_{e q, 63 \mathrm{~Hz}}\right)$ and dredging activity as an anthropogenic noise source was significant but low $(r=0.31)$ (Table 2). The highest correlation between the underwater noise levels $\left(L_{e q, 63 \mathrm{~Hz}}\right.$ and $\left.L_{e q, 125 \mathrm{~Hz}}\right)$ and the ship densities was up to 0.13 and 0.18 , respectively (Tables 2 and 3 ), which could be explained by reduced sound wave propagation in the shallow sea [10,17-19]. Low frequency sound waves below the cutoff frequency do not propagate, because the sound propagates into the sea bed $[20,21]$. The correlation between underwater noise and the cleaning of the sea floor was negligible (Tables 2 and 3), which was expected, because cleaning was performed with an excavator from the mainland.
The relation between underwater noise and the meteorological parameter precipitation - was insignificant. Correlation between the $L_{e q, 63 \mathrm{~Hz}}$ and the wind speed was low to medium and correlation between the $L_{e q, 125 \mathrm{~Hz}}$ and the wind speed was negligible to medium (Tables 2 and 3), which could be explained by the wind-generated waves that break when they are large enough and produce sound [22-28]. That is, underwater ambient sound measurements were, in some cases, used to estimate wind speed over the seas and oceans. The results of these cases showed a very strong correlation between estimated wind speed, provided by a passive acoustic recorder algorithm and in situ measurements of the wind speed $[29,30]$.

Relevant to our study is the problem of selection of frequencies in the $1 / 3$ octave band as indicators of shipping noise. We based our measurements on the European Marine Strategy Framework Directive which focuses on low frequency vessel noise, in $1 / 3$ octave bands with centre frequencies of $63 \mathrm{~Hz}$ and $125 \mathrm{~Hz}$, 
as pressure indicators for ship noise [31]. The two bands were selected based on recordings of ship noise in deep-water areas where, in general, these bands are most powerful [22]. A Danish study of ship noise in shallow water has shown that the aforementioned MSFD indicators of shipping noise turned out to be poor proxies for the impact of noise on small cetaceans at higher frequencies. Thus, higher frequencies were proposed to be included in the assessment of good environmental status, ie in the $1 / 3$ octave band with a centre frequency of $10 \mathrm{kHz}$, which was chosen as a compromise between the range of hearing of small cetaceans and frequency dependent absorption [32]. For this reason, higher frequencies should also be included in further studies of underwater noise in the northern, shallow part of the Adriatic Sea.

\section{Conclusions}

Given the multiple linear regression analysis we conclude that dependent variables were affected by the values of independent variables to a low to moderate degree. The correlation of the underwater noise levels with the dredging activity was significant but low, and the one with the ship densities was insignificant, which could be explained by reduced sound wave propagation in the shallow sea. The correlation between underwater noise and the cleaning of the sea floor was negligible, which could be explained by the fact that cleaning was performed with an excavator from the mainland. The relation between the underwater noise and the meteorological parameter - precipitation was insignificant, while correlation between underwater noise and the wind speed was significant but low to medium, which could be explained by the breaking waves generated by the wind that produced sound.

In the near future, the methodology presented will be used to evaluate underwater noise data measured in the years 2019 and 2020. In addition to MSFD pressure indicators for ship noise in $1 / 3$ octave bands with center frequencies of $63 \mathrm{~Hz}$ and $125 \mathrm{~Hz}$ higher frequencies will be included.

\section{Acknowledgements}

This research was funded by the Slovenian Ministry for the Environment and Spatial Planning. AIS data for the year 2015 were obtained during implementation of the European project BALMAS (2013-2016) from the Italian Coast Guard Headquarters, who gave us permission to use the AIS data for our analyses. AIS data from 2016 to 2018 were obtained by the Slovenian Maritime Administration in the frame of the Ministry for Infrastructure.

\section{References}

[1] Southall, B.L. et al., 'Underwater Noise from Large Commercial Ships - International Collaboration for Noise Reduction', Encyclopedia of Maritime and Offshore Engineering, (LOCATION OF PUBLISHER?), John Wiley \& Sons, 2017 DOI: $10.1002 / 9781118476406$. emoe056.

[2] Marley, S.A., Salgado-Kent, C.P., Erbe, C., Parnum, I.M. 'Effects of Vessel Traffic and Underwater Noise on the Movement, Behavior and Vocalizations of Bottlenose Dolphins in an Urbanized Estuary', Scientific Reports, vol. 7, no. 13,437, 2017, pp. 1-14, DOI:10.1038/s41598-017-13252-z.

[3] Zakarauskas, P., Chapman, D.M.F., Staal, P.R. 'Underwater Acoustic Ambient Noise Levels on the eastern Canadian continental shelf. Journal of the Acoustical Society of America, vol. 87, no. 5, 1990, pp. 2064-2071, DOI:10.1121/1.399333.

[4] Ramji, R., Ramakrishanan, S. 'Analysis of Short Term Temporal Fluctuations in Noise Power Spectrum of Shallow Water Ambient Noise', Symposium on Underwater Technology and Workshop on Scientific Use of Submarine Cables and Related Technologies, Tokyo, IEEE, 2007, pp. 113-119.

[5] Bardyshev, V.I. (2007): 'Underwater Ambient Noise in Shallow Water Areas of the Indian Ocean Within the Tropical Zone', Acoustical Physics, vol. 53, no. 2, pp. 167-171, DOI:10.1134/S1063771007020091.

[6] McDonald, M.A., Hildebrand, J.A., Wiggins, S.M. 'Increases in Deep Ocean Ambient Noise in the Northeast Pacific West of San Nicolas Island, California', Journal of the Acoustical Society of America, no. 120, 2006, pp. 711-718, DOI: $10.1121 / 1.2216565$. 
[7] Willis, M.R. et al., 'Measuring Underwater Background Noise in High Tidal Flow Environments', Renewable Energy, no. 49, 2013, pp. 255-258, DOI:10.1016/ j.renene.2012.01.020.

[8] Bittencourt, L. et al., 'Underwater Noise Pollution in a coastal tropical environment', Marine Pollution Bulletin, vol. 83, no. 1, 2014, pp. 331-336, DOI:10.1016/j.marpolbul.2014.04.026n.

[9] Estabrook, B.J. et al., 'Widespread Spatial and Temporal Extent of Anthropogenic Noise across the Northeastern Gulf of Mexico Shelf Ecosystem', Endangered Species Research, no. 30, 2016 pp. 267-282, DOI:10.3354/esr00743.

[10] Merchant, N.D. et al., ) 'Underwater Noise Levels in UK Waters', Scientific Reports, vol. 6, no. 36,942, 2016, (PAGE REF?) DOI:10.1038/srep36942.

[11] European Parliament, 'Parliamentary Questions', https://www.europarl.europa.eu/doceo/document/ E-8-2019-001209_EN.html, accessed 15 June 2021.

[12] ACCOBAMS, 'Methodological Guide - Guidance on Underwater Noise Mitigation Measures, Seventh Meeting of the Parties to ACCOBAMS', Istanbul, Republic of Turkey, 2019, p. 31.

[13] Directive of the European Parliament and of the Council (EC/2008/56), 'Establishing a Framework for Community Action in the Field of Marine Environmental Policy (Marine Strategy Framework Directive)', Official Journal of the European Union, L164, pp. 19-40.

[14] Popit, A., 'Underwater Noise in the Slovenian Sea', Materials and Geoenvironment - RMZ, vol. 67, no. 3, 2020, pp. 1-15, DOI:10.2478/rmzmag-2020-0018.

[15] Perkovič, M., Batista, M., Luin, B., 'Prikaz in Analiza Gostot Ladijskega Prometa', Fakulteta Za Pomorstvo In Promet, Lyublyana, Univerza v Ljubljani, 2019, (PAGE REF?)

[16] Davis, J.C., Statistics and Data Analysis in geology. John Wiley \& Sons, Inc., 1986New York. (PAGE REF?)

[17] Kozaczka, E., Grelowska, G., 'Propagation of Ship-Generated Noise in Shallow Sea', Polish Maritime Research, vol. 25, no. 2, 2018, pp. 37-46, DOI: 10.2478/pomr-2018-0052.

[18] Meyer, V., Audoly, C.A., 'Comparison Between Experiments and Simulation for Shallow Water Short-Range Acoustic Propagation', International Congress on Sound and Vibration, ICSV 24th, London, United Kingdom, 2017. (PAGE REF?)

[19] Duncan, A.J. et al., 'Characteristics of Sound Propagation in Shallow Water over An Elastic Seabed with a Thin Cap-Rock Layer', Journal of the
Acoustical Society of America, vol. 134, no. 1, 2013, pp. 207-205, DOI:10.1121/1.4809723.

[20] Urick, R.J., Principles of Underwater Sound, New York, McGraw-Hill, 1983 (PAGE REF?)

[21] Robinson, S.P., Lepper, P.A. Scoping Study: Review of Current Knowledge of Underwater Noise Emissions from Wave and Tidal Stream Energy Devices, London, Crown Estate, 2013, (PAGE REF?)

[22] National Research Council, Ocean Noise and Marine Mammals. Washington DC, The National Academies Press, 2003, DOI:10.17226/10564. (PAGE REF?)

[23] Banner, M.L., Cato, D.H. 'Physical Mechanisms of Noise Generation by Breaking Waves - A Laboratory Study', in Natural Physical Sources of Underwater Sound - Sea Surface Sound, Kerman, B.R. (ed.), Dordrecht, Kluwer Academic, 1993, pp. 429-436,

[24] Carey, W.M., Fitzgerald, J.W., Browning, D.G., 'Low Frequency Noise Form Breaking Waves', In, NUSC Technical Report 8783, New London, Connecticut, Naval Underwater System Center 1990, (PAGE REF?)

[25] Kerman. B.R. 'Underwater Sound Generation by Breaking Wind Waves', Journal of the Acoustical Society of America, vol. 75, no. 1, 1984, pp. 149-165, DOI:10.1121/1.390409.

[26] Stewart, M.S., Shallow water ambient noise caused by breaking waves in the surf zone. Ph.D. diss., Naval Postgraduate School, Monterey, California, 1994, (PAGE REF?)

[27] Cuomo, G. et al., 'Breaking Wave Loads at Vertical Seawalls and Breakwaters', Coastal Engineering, vol. 57, no. 4, 2010, pp. 424-439, DOI:10.1016/j. coastaleng.2009.11.005.

[28] Ravindar, R., Sriram, V., Schimmels, S., Stagonas, D. 'Characterization of Breaking Wave Impact on Vertical Wall with Recurve', ISH Journal of Hydraulic Engineering, vol. 25, no. 2, 2019, pp. 153-161, DOI:10.1080/09715010.2017.1391132.

[29] Vagle, S., Large, W.G., Farmer, D.M. An Evaluation of the WOTAN Technique of Inferring Oceanic Winds from Underwater Ambient Sound', Journal of Atmospheric and Oceanic Technology, vol. 7, no. 4, 1990, pp. 576-595, DOI:10.1175/1520-0426(1990)007<0576: AEOTWT>2.0.CO;2.

[30] Pensieri, S. et al., 'Underwater Acoustic Measurements to Estimate Wind and Rainfall in the Mediterranean Sea', Advances in Meteorology, no. 612,512, 2015, DOI:10.1155/2015/612512, (PAGE REF?)

[31] Commission Decision, 'Laying Down Criteria and Methodological Standards on Good 
Environmental Status of Marine Waters and Specifications and Standardized Methods for Monitoring and Assessment, and Repealing Decision 2010/477/EU', Official Journal of the European Union, L125, 2017/848/EU, pp. 43-74.
[32] Hermannsen, L' et al., 'High Frequency Components of Ship Noise in Shallow Water with a Discussion of Implications for Harbor Porpoises (Phocoena Phocoena), Journal of the Acoustical Society of America, vol. 136, no. 4, 2013, pp. 1,640-1,653, DOI:10.1121/1.4893908. 